\title{
Situs-Situs Watu Kandang Di Lembah Sungai Samin, Kabupaten Karanganyar, Jawa Tengah
}

\section{Gunadi Kasnowihardjo}

Keywords: megalithic, stone circle, artifact, agriculture, site, distribution

\section{How to Cite:}

Kasnowihardjo, G. Situs-Situs Watu Kandang Di Lembah Sungai Samin, Kabupaten Karanganyar, Jawa Tengah. Berkala Arkeologi, 15(3), 29-36. https://doi.org/10.30883/iba.v15i3.667

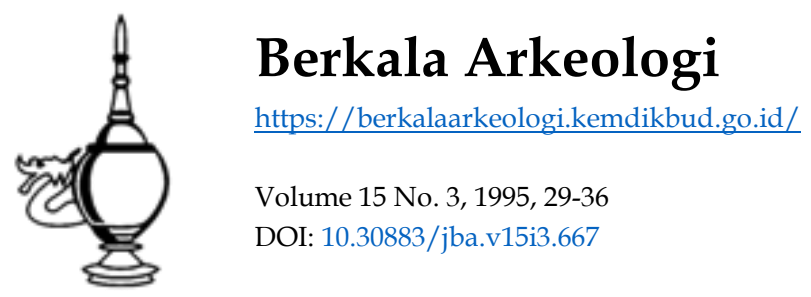

This work is licensed under a Creative Commons Attribution-NonCommercialShareAlike 4.0 International License. 


\title{
SITUS-SITUS WATU KANDANG DI LEMBAH SUNGAI SAMIN, KABUPATEN KARANGANYAR, JAWA TENGAH
}

\author{
G u n a d i \\ (Suaka PSP Provinsi Jawa Tengah)
}

\section{Pendahuluan}

Arkeologi adalah ilmu yang mempelajari manusia dan aktivitasnya di masa lampau berdasarkan sisa-sisa kehidupannya yang didapatkan secara sistematis, baik yang ditemukan di atas maupun di bawah tanah. Sisa-sisa kehidupan tersebut tidak hanya berupa artefak, tetapi lingkungan tempat mereka hidup dan sisa-sisa jasad dari manusia itu sendiri merupakan obyek penelitian. Pada dasarnya arkeologi mempelajari tiga hal yaitu sisa-sisa hasil aktivitas manusia, sisa-si-sa manusia itu sendiri, dan lingkungannya (Whit-ten dan Hunter, 1990: 79-82).

Pengertian lingkungan dalam tulisan ini mencakup dua hal yaitu lingkungan budaya dan lingkungan bukan budaya. Lingkungan bukan budaya (noncultural environment) oleh Butzer dikatakan sebagai salah satu faktor dalam analisis konteks (Butzer 1982:4). Maka dalam penelitian arkeologi perlu kiranya dipertimbangkan aspekaspek lain misalnya lingkungan alam. Dalam mengkaji aktivitas manusia, lingkungan alam merupakan satu unit analisis (Geertz 1963; Miksic 1985;1991; Lewis 1991). Seperti ditegaskan oleh Mundardjito (1993) lingkungan dapat membantu penelitian arkeologi yang sifat datanya terbatas. Selanjutnya dalam penelitian dihindarkan yang bersifat artifact oriented. Lebih lanjut dijelaskan oleh Mundardjito arkeologi tidak hanya mengkaji hubungan antar artefak, tetapi juga antar bentukbentuk data arkeologi lain, serta lingkungan fisik yang dimanfaatkan sebagai sumberdaya (Mundardjito 1993:4).

Dalam kaitannya dengan beberapa pernyataan di atas, maka dalam penelitian arkeologi diperlukan suatu batasan keruangan yang lebih luas dari suatu situs. Disamping dapat dikaitkan antara situs dan lingkungan sumberdayanya, manfaat lain yang diperoleh ialah dilakukan generalisasi-generalisasi yang akan memperluas unitunit analisis. Selain menguraikan kasus perihal situs watu kandang yang tersebar di lembah Kali Samin, tulisan ini juga dimaksudkan untuk menanggapi salah satu proposisi Mundardjito yang menyebutkan bahwa penempatan situs-situs (candi) di daerah Yogyakarta telah mempertimbangkan lingkungan sumberdaya alam yang berpotensi. Kenyataan yang ditemukan pada situssitus candi tersebut akan ditemukan atau tidak pada situs-situs watu kandang, hal ini akan terlihat pada uraian bab-bab di bawah. Dengan demikian apa yang diharapkan Mundardjito bahwa siklus penelitian arkeologi hendaknya dapat bergulir dengan tingkat analisis yang semakin tajam akan terwujud. Apabila kita meminjam istilah Karl Raimund Popper, suatu proposisi atau pernyataan perlu di-verifikasi-kan yaitu membandingkan dengan hasil-hasil penelitian orang lain yang sejenis, untuk mengetahui apakah proposisi tersebut mendapat dukungan atau tidak (Alfons Taryadi 1989:40). Apabila suatu proposisi terbukti banyak mendapat dukungan dari berbagai penelitian, maka proposisi tersebut akan dapat berubah menjadi suatu teori (Harsja W. Bachtiar 1984:25).

Teori bukanlah sesuatu yang abstrak, dan teori adalah suatu kerangka referensi yang bersifat operasional dalam kegunaannya untuk menanggapi kenyataan ataupun fakta yang ditemukan dalam penelitian (Parsudi Suparlan 1984:29). Inilah perlunya suatu penelitian arkeologi yang terintegrasi dalam satu tema tertentu, sehingga beberapa penelitian yang bertemakan sama akan menghasilkan suatu kesimpulan yang jelas dan tegas. Oleh karena itu tepatlah apabila Balai Arkeologi Yogyakarta mulai merintis dengan menyelenggarakan seminar yang bertemakan arkeologi keruangan. Semoga dari seminar ini akan mendapatkan hasil yang memuaskan bagi perkembangan arkeologi Indonesia. Situs watu kandang merupakan situs megalitik yang ditemukan tersebar di sekitar aliran sungai Samin, memanjang dari Desa Pakem, Kecamatan Tawangmangu di sebelah timur hingga Desa Plosorejo, Kecamatan Matesih di sebelah barat, sepanjang \pm 9 $\mathrm{km}$. Watu kandang adalah satu unit bangunan berupa susunan batu-batu utuh dan didirikan dengan denah empat persegi panjang, sedang batu yang terletak di masing-masing sisi lebarnya mempunyai ukuran lebih tinggi dan lebih besar dibanding batu lainnya. Bentuk watu kandang tersebut mirip dengan rectangular encloser of stones yang banyak ditemukan di kepulauan Pasifik (Emory 1934). Telah disebutkan di atas bahwa dalam penelitian situs-situs watu kandang ini mencakup satu wilayah tertentu. Pengertian wilayah (universe) dalam penelitian ini adalah satu daerah di permukaan bumi yang dapat dibedakan dengan daerah tetangganya atas dasar kenampakan karakteristik yang dimiliki (Hadi Sabari 1991:4-8). Kenampakan karakteristik tersebut an- 
tara lain keberadaan situs-situs watu kandang, dan lingkungan sumberdaya alam seperti sungai, gunung, dan sumber air. Lingkungan sumberdaya alam seperti tersebut di atas, merupakan data yang bersifat kekal atau abadi (dependable) dan sangat diandalkan oleh manusia sejak dahulu hingga sekarang, sehingga dapat dijadikan acuan untuk situasi masa lampau (Binford 1983:59).

Hubungan antara budaya manusia dan lingkungan alamnya telah dibicarakan sejak abad IV $B C$, yang oleh Hippocrates dikatakan setiap cuaca dan lingkungan fisik mempunyai pengaruh yang tidak dapat dielakkan oleh manusia (Dixon 1928:266). Pendekatan lingkungan dengan perspektif nomotetik dikenalkan oleh Julian Steward dan Leslie White, yang menurut Marvin Harris merupakan manifestasi dari kebangkitan nomotetik pada pertengahan abad ini (Harris 1984:3889). Apa yang dikatakan Steward sebagai cultural ecology adalah suatu proses adaptasi suatu budaya terhadap lingkungannya (Hammond 1968: 427). Sehubungan dengan hal tersebut di atas, maka data utama yang digunakan dalam penelitian ini ialah situs-situs watu kandang dan variabel lingkungan alam. Sedang data pendukungnya adalah artefak-artefak lepas serta data etnografi. Data tersebut diperoleh dari hasil observasi di lapangan (data primer) dan dari laporan-laporan penelitian yang pernah dilakukan sebelumnya (data sekunder).

Adapun metode yang dipergunakan dalam penelitian situs-situs watu kandang ini ialah metode kualitatif, tetapi dalam pelaksanaannya digunakan pula teknik-teknik kuantitatif seperti penghitungan indeks korelasi antara situs dan variabel lingkungan. Berdasarkan kerangka teoritis dan metode di atas, maka tujuan penelitian ada dua sasaran, yaitu mencari hubungan antara situs watu kandang dan lingkungan sumberdaya alam, yang dapat menunjukkan sejauh mana interaksi antara masyarakat pendukung watu kandang dengan lingkungan sumberdaya alamnya (kearifan lokal). Selanjutnya dalam kaitannya dengan lingkungan budaya maupun bukan budaya, akan ditemukan situs-situs lain seperti situs hunian dan pemujaan. Inilah beberapa hal yang akan diba-has dalam makalah ini.

\section{Situs-situs Watu Kandang Dan Lingkunganya}

Situs adalah satu bidang tanah atau tempat lainnya yang di atas atau di dalamnya terdapat benda purbakala (Ayatrohaedi 1981:87). Sedang pengertian watu kandang seperti telah diuraikan di atas, yaitu satu unit susunan batu-batu utuh yang didirikan, dan berdenah empat persegi pan-jang (rectangular encloser). Situs watu kandang yang dimaksud dalam makalah ini adalah satu bi-dang tanah yang mengandung tinggalan purbaka-ia berupa susunan batu utuh berdenah empat persegi panjang, serta diyakini oleh masyarakat setempat sebagai kuburan budo.

Di daerah penelitian, watu kandang ditemukan tersebar sekitar aliran Kali Samin, dan se-cara berturut-turut dari bagian hulu ke hilir di Du-sun Pakem, Karangrejo, Ngasinan, Kedungsari, Bodagan, Gondang, Selestri, Sabrang, dan Plosorejo. Ke sembilan situs tersebut terletak di tiga lokasi yang berbeda ketinggiannya. Oleh karena itu pada penelitian ini daerah tersebut akan dipisahkan dalam tiga mintakat. Dari masing-masing mintakat akan diwakili sebuah situs watu kandang pewakil. Situs-situs pewakil tersebut antara lain, Situs Watu Kandang Pakem (WK.PAK.) pada bagian hulu, Situs Watu Kandang Ngasinan (WK.NGA.) mewakili bagian tengah, dan Situs Watu Kandang Plosorejo (WK.PLO.) mewakili daerah bagian hilir Kali Samin.

\subsection{Situs Watu Kandang Pakem}

Situs Watu Kandang Pakem terletak di utara aliran Kali Samin, secara administratif masuk Desa Plumbon, Kecamatan Tawangmangu, Kabupaten Karanganyar, Jawa Tengah. Luas situs ini \pm $70.000 \mathrm{M}^{2}$, yang saat ini telah berubah menjadi lahan pertanian, dan sebagian didirikan bangunan seperti gedung sekolah, pabrik, dan rumah penduduk. Beberapa unit watu kandang di Situs Watu Kandang Pakem yang masih dapat diamati ada 20 unit. Dari satuan unit watu kandang tersebut dapat dilakukan pengukuran luas, arah hadap, dan ukuran batu-batunya. Dalam penentuan arah hadap watu kandang, yang dijadikan patokan adalah dua buah batu yang terletak di dua sisi lebar yang mempunyai ukuran lebih tinggi dibanding batu lainnya. Disamping itu, pengukuran arah hadap watu kandang digunakan patokan arah utara kompas, dalam kasus arah hadap watu kandang ini didapatkan kemiringan dari utara ke timur (North to East). Selain pengukuran luas dan arah hadap watu kandang, dilakukan pula pengukuran batu-batu komponen watu kandang. khususnya batu terbesar dan terkecil dalam satu unit watu kandang tersebut. Cara-cara pengukuran seperti di atas juga dilakukan di situs-situs watu kandang yang lain. Adapun ukuran batu, luas, dan arah hadap watu kandang di situs Pakem dapat diperiksa pada tabel berikut. Begitu pula survei permukaan untuk mengetahui kepadatan temuan gerabah, dan tempat-tempat yang berkaitan dengan kegiatan religi (punden), serta data etnografis juga dilakukan di mintakat Pakem, Ngasinan, dan Plosorejo. 
Tabel: 2.1 Ukuran batu dan watu kandang, serta arah hadap Situs Watu Kandang Pakem.

\begin{tabular}{|c|c|c|c|c|c|c|}
\hline \multirow[t]{2}{*}{ Watu Kandang } & \multicolumn{3}{|c|}{ Ukuran Batu } & \multicolumn{2}{|c|}{ Luas WK.(M) } & \multirow[t]{2}{*}{ Arah Hadap } \\
\hline & Tinggi & Lebar & Tebal & Panjang & Lebar & \\
\hline WK.PAK. 1 & $150-80$ & $200-150$ & $40-40$ & 6 & 4 & $U 100^{\circ} \mathrm{T}$ \\
\hline WK.PAK. 2 & $100-90$ & $150-100$ & $40-40$ & 6 & 4 & $\cup 100^{\circ} \mathrm{T}$ \\
\hline WK.PAK. 3 & $90-100$ & $200-130$ & $35-30$ & 4.5 & 2.5 & $\cup 100^{\circ} \mathrm{T}$ \\
\hline WK.PAK. 4 & $165-115$ & $220-150$ & $40-30$ & 4 & 2 & $\cup 100^{\circ} \mathrm{T}$ \\
\hline WK.PAK. 5 & $140-90$ & $190-120$ & $40-30$ & 4.5 & 2 & $\cup 95^{\circ} \mathrm{T}$ \\
\hline WK.PAK. 6 & $140-100$ & $220-80$ & $40-30$ & 4.5 & 2 & $U 90^{\circ} \mathrm{T}$ \\
\hline WK.PAK. 7 & $110-80$ & $100-90$ & $40-40$ & 3 & 1.5 & $\cup 90^{\circ} \mathrm{T}$ \\
\hline WK.PAK. 8 & $100-50$ & $100-80$ & $40-35$ & 3 & 1.5 & $\cup 90^{\circ} \mathrm{T}$ \\
\hline WK.PAK. 9 & $100-50$ & $120-70$ & $30-30$ & 2.5 & 1 & $\cup 100^{\circ} \mathrm{T}$ \\
\hline WK.PAK. 10 & $60-60$ & $90-40$ & $30-30$ & 2 & 1 & $\cup 100^{\circ} \mathrm{T}$ \\
\hline WK.PAK. 11 & $60-60$ & $90-40$ & $30-30$ & 2 & 1 & $\cup 100^{\circ} \mathrm{T}$ \\
\hline WK.PAK. 12 & $160-150$ & $130-120$ & $40-40$ & 3 & 1.5 & $\cup 100^{\circ} \mathrm{T}$ \\
\hline WK.PAK. 13 & $150-100$ & $145-90$ & $40-40$ & 4 & 2.5 & $\cup 100^{\circ} \mathrm{T}$ \\
\hline WK.PAK. 14 & $160-60$ & $100-120$ & 40.40 & 3.5 & 2 & $\cup 95^{\circ} \mathrm{T}$ \\
\hline WK.PAK. 15 & $200-80$ & $140-100$ & $50-35$ & 4 & 2 & $\cup 106^{\circ} \mathrm{T}$ \\
\hline WK.PAK.16 & $100-80$ & $110-90$ & $40-30$ & 2.5 & 1.5 & U $95^{\circ} \mathrm{T}$ \\
\hline WK.PAK. 17 & $130-100$ & $190-170$ & $50-40$ & 3 & 1.5 & $\cup 95^{\circ} \mathrm{T}$ \\
\hline WK.PAK. 18 & $120-110$ & $190-120$ & $40-40$ & 4 & 2 & $\cup 95^{\circ} \mathrm{T}$ \\
\hline WK.PAK. 19 & $150-100$ & $140-130$ & $50-40$ & 4 & 2 & U $100^{\circ} \mathrm{T}$ \\
\hline WK.PAK. 20 & $310-65$ & $260-90$ & $60-30$ & 4 & 2 & $\cup 95^{\circ} \mathrm{T}$ \\
\hline
\end{tabular}

Sumber:Pengukuran di Lapangan oleh penulis.

Dalam satuan situs, situs-situs watu kandang dapat dikorelasikan dengan variabel lingkungan sumberdaya alam seperti ketinggian tempat, kemiringan lereng, sungai, sumber air, kesuburan tanah, dan material batuan andesitis.
Korelasi antara Situs Watu Kandang Pakem dan variabel lingkungan sumberdaya alam dapat diperiksa pada tabel di bawah.

Tabel:2.1a Korelasi antara Situs Watu Kandang Pakem dan lingkungan sumberdaya alam

\begin{tabular}{|c|c|c|c|c|c|}
\hline $\begin{array}{c}\text { Variabel } \\
\text { lingkungan } \\
\text { Situs }\end{array}$ & $\begin{array}{c}\text { Tgi.dpal. } \\
(\mathrm{M})\end{array}$ & $\begin{array}{c}\text { Kemiringan } \\
(\%)\end{array}$ & $\begin{array}{c}\text { Jrk.dgn. sungai } \\
(\mathrm{M})\end{array}$ & $\begin{array}{c}\text { Jrk.dgn. Sendang } \\
(\mathrm{M})\end{array}$ & $\begin{array}{c}\text { Bentuk } \\
\text { lahan }\end{array}$ \\
\hline WK. PAKEM & 700 & 0.84 & 100 & 120 & $\mathrm{v3}$ \\
\hline
\end{tabular}

Keterangan: Bentuk lahan V3 = lahan subur

Jarak situs dan sumber material andesitis = antara situs dan sungai.

Di atas telah disebutkan yang dimaksud lingkungan dalam makalah ini selain lingkungan sumberdaya alam (lingkungan bukan budaya), situs-situs watu kandang akan dikaitkan pula dengan lingkungan budaya antara lain: kepadatan gerabah yang ditemukan di luar situs watu kandang, serta tempat-tempat yang berhubungan dengan sistem religi (data etnografi). Keberadaan punden, kepadatan temuan gerabah, dan data etnografis dapat diketahui dari hasil survei yang dilakukan di luar situs watu kandang.

\subsection{Situs Watu Kandang Ngasinan}

Telah disebutkan di atas bahwa Situs Watu Kandang Ngasinan merupakan sampling unit atau situs pewakil dari situs-situs watu kandang yang ditemukan di sekitar aliran Kali Samin ba-gian tengah. Situs Watu Kandang Ngasinan ter-letak di Desa Karangbangun, Kecamatan Mate-sih. 
Kabupaten Karanganyar, Jawa Tengah, kira-kira $150 \mathrm{~m}$ selatan Kali Samin. Situs ini terbelah jalan yang menghubungkan Matesih dan Tawangmangu, serta merupakan situs watu kandang paling luas yang ditemukan di wilayah $\mathrm{Ke}$ camatan Matesih. Menurut laporan penelitian Goenadi Nitihaminoto (1977-1978) di lokasi tersebut tercatat 160 unit watu kandang, tetapi saat penulis melakukan penelitian di lokasi tersebut, watu kandang yang masih dapat diamati 27 unit. Sebagian besar watu kandang telah rusak oleh kegiatan petani penggarap lahan pertanian, sebab situs tersebut terletak pada lahan pertanian. Selain itu, batu-batu dari beberapa unit watu kan- dang sengaja dipecahkan oleh para pencari batu untuk dijual sebagai material bangunan. Seperti halnya watu kandang di situs Pakem, dalam pengamatan ke 27 unit watu kandang situs Ngasinan antara lain dilakukan pengukuran batu-batu dari komponen watu kandang, ukuran luas watu kandang, dan arah hadap watu kandang tersebut Data tersebut di atas dapat diperiksa pada tabel di bawah. Di mintakat Ngasinan, selain dilakukan survei permukaan di luar situs watu kandang, dilakukan pula penggalian penjajagan (test pit) di WK.NGA.3, WK.NGA.4, dan WK.KED.8.

Tabel:2.2 Ukuran batu dan watu kandang, serta arah hadap watu kandang situs Ngasinan

\begin{tabular}{|c|c|c|c|c|c|c|}
\hline \multirow[t]{2}{*}{ Watu Kandang } & \multicolumn{3}{|c|}{ Ukuran Batu (CM) } & \multicolumn{2}{|c|}{ Luas WK.(M) } & \multirow[t]{2}{*}{ Arah Hadap } \\
\hline & Tinggi & Lebar & Tebal & Panjang & Lebar & \\
\hline WK.NGA. 1 & $140-80$ & $120-100$ & $40-40$ & 3.5 & 2 & $\mathrm{U} 95^{\circ} \mathrm{T}$ \\
\hline WK.NGA. 2 & $110-90$ & $100-100$ & $50-40$ & 4 & 3 & $\cup 100^{\circ} \mathrm{T}$ \\
\hline WK.NGA. 3 & $50-30$ & $70-40$ & $30-20$ & 1.25 & 1 & $\cup 100^{\circ} \mathrm{T}$ \\
\hline WK.NGA 4 & $120-50$ & $100-90$ & $30-30$ & 3 & 2.5 & $U 105^{\circ} \mathrm{T}$ \\
\hline WK.NGA. 5 & $90-60$ & $150-70$ & $40-40$ & 3 & 2 & $\cup 100^{\circ} \mathrm{T}$ \\
\hline WK.NGA. 6 & $100-50$ & $100-70$ & $50-20$ & 3 & 2 & $\cup 100^{\circ} \mathrm{T}$ \\
\hline WK.NGA. 7 & $150-80$ & $140-100$ & $50-50$ & 4 & 2 & $\cup 100^{\circ} \mathrm{T}$ \\
\hline WK.NGA. 8 & $110-40$ & $100-70$ & $40-20$ & 4 & 2 & $\cup 100^{\circ} \mathrm{T}$ \\
\hline WK. NGA. 9 & $120-100$ & $160-120$ & $50-40$ & 5 & 4 & $\cup 100^{\circ} \mathrm{T}$ \\
\hline WK.NGA. 10 & $90-60$ & $110-80$ & $40-30$ & 4 & 2 & $\cup 100^{\circ} \mathrm{T}$ \\
\hline WK.NGA. 11 & $120-80$ & $200-100$ & $50-40$ & 5 & 3.5 & $\cup 105^{\circ} \mathrm{T}$ \\
\hline WK.NGA. 12 & $90-80$ & $170-120$ & $30-30$ & 4 & 3.5 & $\cup 100^{\circ} \mathrm{T}$ \\
\hline WK.NGA. 13 & $160-100$ & $300-120$ & $50-40$ & 8 & 5.5 & $\cup 110^{\circ} \mathrm{T}$ \\
\hline WK.NGA. 14 & $130-80$ & $130-90$ & $40-30$ & 6 & 4 & $\cup 110^{\circ} \mathrm{T}$ \\
\hline WK. NGA. 15 & $140-120$ & $110-100$ & $40-30$ & 5 & 2 & $\cup 105^{\circ} \mathrm{T}$ \\
\hline WK.NGA.16 & $70-70$ & $85-70$ & $30-20$ & 4 & 2 & $\cup 100^{\circ} \mathrm{T}$ \\
\hline WK. NGA. 17 & $150-70$ & $150-90$ & $40-30$ & 4 & 3 & $\cup 120^{\circ} \mathrm{T}$ \\
\hline WK.NGA.18 & $160-100$ & $120-110$ & $40-30$ & 4 & 2 & $\cup 115^{\circ} \mathrm{T}$ \\
\hline WK NGA.19 & $125-90$ & $150-110$ & $40-40$ & 4 & 3 & $U 125^{\circ} \mathrm{T}$ \\
\hline WK.NGA. 20 & $300-170$ & $290-150$ & $50-40$ & 4 & 3.5 & $\cup 115^{\circ} \mathrm{T}$ \\
\hline WK.NGA.21 & $145-75$ & $110-90$ & $40-30$ & 4 & 3 & $\mathrm{U} 120^{\circ} \mathrm{T}$ \\
\hline WK NGA.22 & $150-75$ & $150-80$ & $50-40$ & 4 & 2 & $\cup 120^{\circ} \mathrm{T}$ \\
\hline WK.NGA.23 & $100-60$ & $120-50$ & $30-30$ & 3.5 & 2 & U $110^{\circ} \mathrm{T}$ \\
\hline WK.NGA.24 & $190-70$ & $120-100$ & $30-30$ & 4 & 3 & $\mathrm{U} 120^{\circ} \mathrm{T}$ \\
\hline WK. NGA.25 & $90-80$ & $130-120$ & $40-30$ & 4 & 3 & $\cup 95^{\circ} \mathrm{T}$ \\
\hline WK.NGA.26 & $130-140$ & $100-70$ & $50-40$ & 4 & 2 & $\cup 100^{\circ} \mathrm{T}$ \\
\hline WK.NGA. 27 & $90-75$ & $160-140$ & $50-40$ & 5 & 2 & $U 105^{\circ} \mathrm{T}$ \\
\hline
\end{tabular}

Sumber: Pengukuran langsung di Lapangan

Tabel:2.2a Korelasi antara Situs Watu Kandang Ngasinan dan Lingkungan sumberdaya alamnya.

\begin{tabular}{|c|c||c||c|c|c|}
\hline $\begin{array}{c}\text { Variabel } \\
\text { Lingkungan } \\
\text { Situs }\end{array}$ & $\begin{array}{c}\text { Tgi.dpal. } \\
\text { (M) }\end{array}$ & $\begin{array}{c}\text { Kemiringan } \\
(\%)\end{array}$ & $\begin{array}{c}\text { Jrk.dgn.sungai } \\
\text { (M) }\end{array}$ & $\begin{array}{c}\text { Jrk.dgn.sendang } \\
(\mathrm{M})\end{array}$ & $\begin{array}{c}\text { Bentuk } \\
\text { Lahan }\end{array}$ \\
\hline WK.NGASINAN & 493 & 1.41 & 150 & 140 & $\mathrm{~V} 3$ \\
\hline
\end{tabular}

Keterangan: Bentuk lahan V3 = lahan subur. 


\subsection{Situs Watu Kandang Plosorejo}

Situs Watu Kandang Plosorejo terletak \pm 4 $\mathrm{km}$ arah barat laut dari Situs Watu Kandang Ngasinan, secara administratif terletak di Desa Plosorejo, Kecamatan Matesih, Kabupaten Karanganyar. Sisa-sisa watu kandang di situs Plosorejo saat penulis melakukan pengamatan di lokasi tersebut hanya menemukan 4 unit watu kandang. Sekalipun situs tersebut terletak di perkampungan penduduk, tetapi juga tidak terlepas dari "pengrusakan". Beberapa tahun yang lalu banyak watu kandang yang sengaja dipecahkan saat pelebaran jalan. Batu-batu komponen dari watu kandang tersebut sebagian besar untuk pengerasan jalan dan sebagian untuk pembangunan pagar yang dilakukan secara seragam oleh masyarakat setempat. Keempat unit watu kandang yang selamat dari pengrusakan karena masih dikeramatkan oleh masyarakat di sekitarnya. Selain watu kandang, pengamatan di mintakat Plosorejo juga melakukan survei di daerah sekitar situs untuk mendapatkan data lain seperti lingkungan sumberdaya alam maupun lingku-ngan budaya (konteks arkeologis dan etnografis).

Tabel: 2.3 Ukuran batu, luas dan arah hadap Situs Watu Kandang Plosorejo

\begin{tabular}{|c|c|c|c|c|c|c|}
\hline \multirow[t]{2}{*}{ Watu Kandang } & \multicolumn{3}{|c|}{ Ukuran Batu (CM) } & \multicolumn{2}{|c|}{ Luas WK.(M) } & \multirow[t]{2}{*}{ Arah Hadap } \\
\hline & Tinggi & Lebar & Tebal & Panjang & Lebar & \\
\hline WK.PLO 1 & $210-140$ & $140-110$ & $50-40$ & 4 & 2 & $U 125^{\circ} \mathrm{T}$ \\
\hline WK.PLO. 2 & $190-180$ & $150-120$ & $80-80$ & 5 & 2 & $\cup 125^{\circ} \mathrm{T}$ \\
\hline WK.PLO. 3 & $125-100$ & $160-115$ & $80-50$ & 8 & 3 & U $125^{\circ} \mathrm{T}$ \\
\hline WK.PLO. 4 & $200-100$ & $170-130$ & $70-40$ & 8 & 3 & $\cup 120^{\circ} \mathrm{T}$ \\
\hline
\end{tabular}

Sumber:Pengukuran langsung di lapangan

Tabel:2.3a Korelasi antara Situs Watu Kandang Plosorejo dan Sumberdaya alam

\begin{tabular}{|c||c|c||c||c||c|}
\hline $\begin{array}{c}\text { Variabel } \\
\text { Lingkungan } \\
\text { Situs }\end{array}$ & $\begin{array}{c}\text { Tgi.dpal. } \\
(\mathrm{M})\end{array}$ & $\begin{array}{c}\text { Kemiringan } \\
(\%)\end{array}$ & $\begin{array}{c}\text { Jrk.dgn.sungai } \\
(\mathrm{M})\end{array}$ & $\begin{array}{c}\text { Jrk.dgn.sendang } \\
(\mathrm{M})\end{array}$ & $\begin{array}{c}\text { Bentuk } \\
\text { Lahan }\end{array}$ \\
\hline \hline WK.PLO. & 350 & 0.28 & 100 & 100 & $\mathrm{~V} 3$ \\
\hline
\end{tabular}

3. Korelasi Antara Situs Watu Kandang Dan Lingkungannya.

3.1. Korelasi Antara Situs dan Lingkungan Bukan Budaya.

Untuk mencari indeks korelasi antara situs watu kandang dan potensi sumberdaya alam diusulkan satu rumusan sebagai berikut.

- setiap sub variabel lingkungan sumberdaya alam merupakan satuan yang diberi bobot (nilai)

Tabel:3.1.1 Situs dan jarak dgn.sungai

\begin{tabular}{|l|c|c|c|}
\hline Jumlah situs & $\leq 500 \mathrm{M}$ & $500-1000 \mathrm{M}$ & $\geq 1000 \mathrm{M}$ \\
\hline $100 \%$ & 3 & - & - \\
\hline Bobot $=100$ & $100 \times 3=3$
\end{tabular}

Tabel:3.1.3 SItus dan kellngetan tempat

$\left[\begin{array}{lll}\hline \text { Jumlah situs } & \text { Lowland } & \text { Mid.land } \\ \hline 100 \% & \text { Highland }\end{array}\right]$

Bobot $=100 / 100 \times 2=2$
3 = baik, 2 = cukup baik, 1 = kurang baik, dan 0 $=$ jelek.

- indeks kwalitas lingkungan tersebut dapat diperoleh dengan menggunakan formula jumlah situs dalam \% dikalikan bobot masing-masing sub variabel.

Adapun hasil penghitungan bobot potensi sumberdaya lingkungan alam dalam kaitannya dengan penempatan situs watu kandang dapat diperiksa pada tabel berikut.

Tabel:3.1.2 Situs dan jarak dengan sendang

\begin{tabular}{|c|c|c|c|}
\hline Jumlah situs & $\leq 500 \mathrm{M}$ & $500-1000 \mathrm{M}$ & $\geq 500 \mathrm{M}$ \\
\hline $100 \%$ & $\cdot 3$ & - & \\
\hline Bobot $=100$ & $100 \times 3=3$
\end{tabular}


Tabel:3.1.4 Situs dan kemiringan lereng

\begin{tabular}{|c|c|c|c|}
\hline Jumlah situs & $\leq 2 \%$ & $2-15 \%$ & $\geq 15 \%$ \\
\hline $100 \%$ & 3 & - & \\
\hline
\end{tabular}

Bobol $=100 / 100 \times 3=3$

Tabel:3.1.5 Situs dan bentuk lahan/kesuburan

\begin{tabular}{l|l|l|l|l|}
\hline $\begin{array}{l}\text { Jumlah } \\
\text { Situs }\end{array}$ & $\begin{array}{l}\text { V4 } \\
\text { Subur }\end{array}$ & $\begin{array}{l}\text { V3 } \\
\text { Cukup } \\
\text { subur }\end{array}$ & $\begin{array}{l}\text { V2 } \\
\text { Kurang } \\
\text { subur }\end{array}$ & $\begin{array}{l}\text { V1 } \\
\text { Tidak } \\
\text { subur }\end{array}$ \\
\hline $100 \%$ & - & 2 & - & - \\
\hline
\end{tabular}

Bobot $=100 \mid 100 \times 2=2$

Indeks bobot nilai kwalitas lingkungan sumberdaya alam dapat dihitung dengan menggunakan rumus:

$\begin{array}{cc}\text { Jumlah bobot } & 13 \\ \text { Jumlah sub variabel } & 5\end{array}$

Apabila nilai indeks

$3=$ bobot kwalitas lingkungan baik

2 = bobot kwalitas lingkungan cukup baik

$1=$ bobot kwalitas lingkungan kurang baik

\subsection{Korelasi Antara Situs Watu Kandang dan Lingkungan Budaya.}

Sebelum mengkorelasikan antara situs watu kandang dan variabel lingkungan budayanya, terlebih dahulu akan dijelaskan tentang fungsi watu kandang tersebut. Kerangka pikir penulis sebelum memulai pengumpulan data, telah memprediksikan bahwa situs watu kandang adalah situs kubur. Untuk membuktikannya perlu dicari unsurunsur yang dapat menyatakan bahwa watu kandang adalah kubur. Ada empat gejala yang harus dicari untuk menunjukkan suatu kubur, yaitu tanda kubur, lubang kubur, jasad yang dikubur, dan benda bekal kubur. Dari keempat unsur di atas, tiga diantaranya telah ditemukan baik oleh penulis maupun para peneliti sebelumnya. Hanya unsur jasad yang dikubur (sisa-sisa tulang belulang) belum dapat dibuktikan. Tetapi setelah dilakukan tes keasaman tanah di tiga mintakat dari kedalaman 50 CM-200 CM, diketahui bahwa tanah di Jaerah penelitian termasuk kategori acid. Didukung oleh volume air tanah yang cukup besar serta kemiringan lereng secara makro cukup tinggi $(12 \%)$, sehingga sisa-sisa jasad manusia yang dikubur di tempat tersebut akan hancur dan tercuci oleh air tanah. Oleh karena itu sangat kecil kemungkinannya dapat menemukan sisa-sisa jasad tersebut. Data lain yang memperkuat watu kandang sebagai kubur ialah temuan lempengan emas penutup mata dan hidung (cover of eyes and nose) mayat.

Ada tiga sub variabel lingkungan budaya yang dapat dikorelasikan dengan situs watu kan- dang, yaitu sub variabel kepadatan temuan gerabah, punden, dan sistem upacara (seperti misalnya bersih desa).

Hasil survei yang dilakukan di luar areal situs watu kandang pada masing-masing mintakat, diketahui bahwa kepadatan gerabah terkonsentrasi tidak jauh dari sumber air atau sendang. Gerabah yang ditemukan di luar situs watu kandang tersebut beberapa diantaranya sama dengan gerabah yang ditemukan di watu kandang. Punden adalah suatu tempat yang oleh masyarakat diyakini sebagai lokasi bersemayam tokoh supernatural, yaitu cikal bakal desa yang dapat memberikan "kesejahteraan" maupun "kesengsaraan" Pada saat-saat tertentu, baik pada waktu diadakan upacara secara kolektif maupun individual, di tempat tersebut dilakukan penyembelihan binatang korban (seekor kambing jantan dan kendhit) Di mintakat Pakem dan Plosorejo, kepala dan keempat kaki (kikil) di tanam di pusat dan keempat sudut desa. Sedang di mintakat Ngasinan kebiasaan seperti di atas sudah mengalami perubahan, kepala dan kaki kambing korban semuanya ikut dimasak. Tetapi penyembelihan tetap dilakukarı di punden, dengan darah dibiarkan jatuh ke tanah. Kepercayaan kepada tokoh supernatural yang diyakini dapat memberikan pertolongan (helpful) dan kerusakan (harmful). Keyakinan seperti tersebut merupakan sisa-sisa kepercayaan asli (nature religion), yang berasal dari konsep awal yang ditemukan oleh manusia berdasarkan fenomena yang terjadi di sekelilingnya (Crawford H. Toy 1948:1-4). Bentuk kubur seperti watu kandang di atas, jelas bukan kubur dari kepercayaan Hindu, Islam ataupun agama-agama lain. Sehingga watu kandang tersebut lebih tepat apabila dihubungkan dengan kepercayaan pra Hindu atau sering disebut dengan kepercayaan megalitis. Berdasarkan dua hal di atas, maka kebiasaan atau tradisi yang berkaitan dengan punden kemungkinan besar merupakan sisa-sisa tradisi dari masyarakat pendukung watu kandang

\section{Penutup}

Beberapa hal yang dapat disimpulkan dalam makalah ini antara lain 
- Ada beberapa keuntungan dari studi arkeologi dengan mencakup ruang yang lebih luas dari suatu situs, antara lain akan memperluas unitunit analisis dan lebih memperkuat kesahihan data (dapat dilakukan generalisasi). Setelah fungsi watu kandang diketahui sebagai kubur, dapat diketahui bahwa lokasi hunian maupun pemujaan tidak jauh dari lokasi kubur. Dengan demikian sebagian dari pola permukiman masyarakat watu kandang dapat ditentukan.

- Pada kasus penelitian di situs-situs watu kandang yang salah satu tujuannya memverifikasi proposisi Mundardjito (1993), dapat dinyatakan bahwa pada masyarakat pendukung situs-situs watu kandang, dalam menempatkan monumen (kubur watu kandang) telah mempertimbangkan lingkungan sumberdaya alamnya (kearifan lokal terhadap pemanfaatan lingkungan bukan budaya yang ada di sekitarnya).

- Dalam makalah ini beberapa unit analisis seper-ti pola persebaran situs, ukuran batu dan watu kandang, arah hadap watu kandang maupun temuan lepas lainnya, tidak akan dijelaskan dan merupakan bahan kajian pada kesempat-an lain.

\section{KEPUSTAKAAN}

Alfons Taryadi, 1989. Epistemologi Pemecahan Masalah Menurut Karl R Popper Gramedia, Jakarta.

Arthur and Allan, 1977. Geography and Man's Environment John Willey and Sons New York, USA.

Ayatrohedi, 1981.Kamus Istilah Arkeologi I Pusat Pembinaan dan Pengembangan Bahasa, Depdikbud, Jakarta.

Bachtiar,Harsya W.1984.Konsep, Definisi, Teori, dan Penggunaannya, dalam Parsudi Suparlan (ed) Metode Penelitian Kebudayaan Direktorat Jenderal Kebudayaan, Depdikbud.

Bellwood,Peter S.1979. Settlement Pattern dalam Jesse D.Jennings:The Prehistory of Polynesia, Harvard University Press

Binford,Lewis R.1972.An Archaeological Perspective, Seminar Press, New York.

,1983. Working at Archaeology, Academic Press Inc. USA

.1988. In Pursuit of The Past, Thames and Hudson Ltd. USA.
Brothwell,Don R.1972.Digging up Bones. Trusees of The British Museum, London.

Butzer, Karl W.1982. Archaeology as Human Ecology, Cambridge University Press.

Crawford H.Toy 1948. History of Religions, Harvard University Press, USA.

Dixon,Roland.1928. The Building of Cultures Charles Scribner's and Son's, USA

Drennan, Robert D.1991. Cultural Evolution, Human Ecology and Empincal Research, Profiles in Cultural Evolution, edited by $A$. Terry Rambo and Kathleen Gillogy, Musum of Anthropology, University of Michigan.

Emory,Kenneth P.1934 Archaeology of The Pacific Equatorial Islands The Museum Honolulu

Fagan,Brian M.1992. People of The Earth, Harper Collins Publishers, New York, USA.

Geertz,Clifford, 1963.Agricultural Involution: The Process of Ecological Change in Indonesia, Berkeley, University of California Press

Goenadi Nh.1977-1978.Laporan Ekskavasi Matesih Proyek Penelitian dan Penggalian Purbakala, Yogyakarta (tidak diterbitkan).

Hadi Sabari,1991.Konsepi Wilayah dan Prinsip Kewilayahan Penerbit Hardana, Yogyakarta.

Hammond, Peter B. 1968. Cultural and Social Anthropology The Macmillan Company New York.

Hardesty, Donald L. 1977. Ecological Anthropology John Willey and Sons Inc. USA.

Harris, Marvin.1984.Kemunculan Teori Antropologi Dewan Bahasa dan Pustaka Kementerian Pelajaran Malaysia, Kuala Lumpur.

Hodder \& Orton.1976.Spatial Analysis in Archaeology, Cambridge University Press

Ian Morris.1987.Burial and Ancient Society Cambridge University Press.

Jamulya, 1991.Laporan Penelitian Katena Tanah :Suatu Studi Kasus di Lereng Gunungapi Lawu Bagian Barat Fak. Geografi, UGM. 
Lewis, ED. 1991. The Relations of the Social Order, Agricultural Practice and Environment in Tona'ai, Flores, Bulletin of the Indo-Pacific Prehistory Association, No. 10, Canberra: IPPA-Jakarta: API.

Miksic,John N.1986. Pola Pemukiman dan Peradaban di Asia Tenggara Ikatan Ahli Arkeologi Indonesia-Komisaliat IY-Jawa Tengah (tidak diterbitkan).

Mundardjito. 1985. Metode Penelitian Pemukiman Arkeologi,REHPA,Pusat Penelitian Arkeologi Nasional.

, 1989. Pola Permukiman Mikro Masa Ma. japahit di Trowulan, Mojokerto Jawa Timur Universitas Indonesia (belum diterbitkan)
-. 1993.Pertimbangan Ekologi Dalam Penempatan Situs-Situs Masa Hindu-Buda di Daerah Yogyakarta: Kajlan Arkeologi Ruang Skala Makro Disertasi, UI.

Parsudi,Suparlan, 1984.Kerangka Teori, Model Teori. Dan Masalah Penelitian, dalam Metode Penelitian Kebudayaan, Depdikbud.

Shackley,Myra.1981. Environmental Archaeology George Allen and Unwin Publishers Ltd. London.

Soejono,R.P.1977.Sejarah Nasional Indonesia I, Balai Pustaka, Jakarta.

Whitten dan Hunter, 1990. Anthropology Contemporary Perspectives A Division of Scott, Foresman and Company, USA. 